\title{
INCREASING THE ACCURACY OF DATING AND TIME DISTRIBUTION THROUGH \\ LATE PLEISTOCENE LAKE SEDIMENTS \\ BY \\ POLLEN AEROSOL SEQUENCING
}

by

Ronald J. Litwin ${ }^{1}$

Open-File Report 00-036

This report is preliminary and has not been reviewed for conformity with U.S. Geological Survey editorial standards (or with the North American Stratigraphic Code). Any use of trade, product, or firm names is for descriptive purposes only and does not imply endorsement by the U.S. Government.

\footnotetext{
${ }^{1}$ MS926A, USGS National Center, Reston, VA 20192
} 
INCREASING THE ACCURACY OF DATING AND TIME DISTRIBUTION THROUGH

LATE PLEISTOCENE LAKE SEDIMENTS BY POLLEN AEROSOL SEQUENCING

Ronald J. Litwin, MS 926A, U.S. Geological Survey, Reston, VA 20192

\section{ABSTRACT}

Age control in Owens Lake sediments is effectively limited at present to the analytical limit of ${ }^{14} \mathrm{C}$ analyses ( $<35 \mathrm{ka}$ ) and the occurrence of the Bishop Ash (759 ka). A number of recently published attempts to interpolate between these two control points are based on unrealistic geologic models. Radiometric dates are available for the interval between these two age controls, but in the lacustrine sequence preserved in Searles Lake, located downflow in this same hydrologic drainage. However, airborne pollen (pollen aerosol) fallout from the Sierra Nevada provided a characteristic and continuous common detrital signal to both Owens Lake and Searles Lake throughout the late Pleistocene, thereby enabling the fossil pollen record to be used as a means for exporting absolute ages from Searles Lake to Owens Lake. Provisional ages for intermittent depths then were assigned by interpolating linearly between the newly imported control points in Owens Lake. These results, based on a total of more than 350 pollen assemblage analyses and 5 published U-Th dates from Searles Lake, appear to provide a geologically reasonable and accurate age model for Owens Lake sediments through the interval spanning 65-135 ka (which includes all of the Last Interglacial interval).

\section{INTRODUCTION}

Climate research has two common methods of comparing sequential trends in stratigraphic records: 1) comparison by unit depth, and 2) comparison by unit time. The first method is a directly measurable quantity. However, it is more desirable in most cases to compare paleobiological, paleomagnetic, sedimentological, or geochemical trends in two separate geologic sections against a common timescale. This study demonstrates the use of airborne pollen fallout 
as a vector for achieving relatively accurate time distribution in sediments of a late Pleistocene proxy climate record that lacks significant temporal control.

The Owens Lake sedimentary record contains important information on Late Pleistocene to Holocene proxy climate trends (Benson and Bischoff, 1993; Bischoff, 1993; Bradbury, 1993; Litwin et al., 1993; Woolfenden, 1993; Benson et al., 1996, Benson et al., 1997; Bischoff et al., 1997a; Bischoff et al., 1997b; Bradbury, 1997a; Bradbury, 1997b; Litwin et al., 1997; Menking et al., 1997; Sarna-Wojcicki et al., 1997; Bischoff et al., 1998; Bradbury and Paquette, 1998; Forester and Carter, 1998; Litwin, 1998). Many of these studies used the age model developed for the longest core through Owens Lake (OL-92), which was based on a calculation of mass accumulation rate (MAR) of sediments (Bischoff, 1993; Bischoff et al., 1997b). Although this model is very precise, its fails to accommodate a fundamental geologic premise. In most sedimentary environments, deposition of coarse-grained clastics (e.g., coarse sands) occurs at a substantially different rate than deposition of fine-grained clastics (e.g., clay). The MAR time model, however, produced a nearly linear rate of deposition of approximately $40 \mathrm{~cm} \mathrm{ky}^{-1}$ through strongly heterogeneous sediments. The coarse-grained sediments in OL-92 included coarse-tomedium siliciclastic sand, siliciclastic pebbles and granules, and calcareous ostracode carapaces (both primary and reworked clasts). The fine-grained sediments included siliciclastic and calcareous clays, silts, and fine sands, that frequently have glacial outwash (including rock flour) as their source.

Attempts to date Owens Lake sediments are confounded by multiple factors, however. Difficulties include, but are not limited to: 1) a limited understanding of the "carbon reservoir effect"-- an error introduced by assimilation of "old" carbon into living organisms and thus into bulk lacustrine sediment-- and its effect on the accuracy of AMS ${ }^{14} \mathrm{C}$ dating results (e.g., Reid et al., 1995); 2) The relatively young analytical limit of ${ }^{14} \mathrm{C}$ dating (approximately $30-35 \mathrm{ka}$ ), 
3) difficulty in discriminating primary and reworked ostracode specimens, for accurate geochemical dating using U-series radioisotopes (Bischoff et al., 1998); and 4) incomplete understanding of the assimilation (during life) and postmortem change in radioisotopes (here, uranium and thorium) incorporated within ostracode carapaces. As a result of these complications, the Owens Lake section has its best temporal control in its shallowest and deepest intervals: 1) within the time domain of radiocarbon analyses ( $<35 \mathrm{ka})$, and 2) adjacent to the Bishop Ash, a chronostratigraphic marker found at approximately $307 \mathrm{~m}$ depth, and previously dated at approximately 759 ka (Sarna-Wojcicki and Pringle, 1992). Several "within-Brunhes" paleomagnetic excursions that once were proposed to provide robust age control in OL-92 (Glen and Coe, 1997) since have been demonstrated to be measurements that were taken erroneously, on sediment intervals physically disturbed by coring (Rosenbaum et al, 1998). This leaves nearly $300 \mathrm{~m}$ of climatically useful core-- representing more than 700,000 years duration-- with insufficient age control. The MAR age model for core OL-92 (Bischoff, 1993; Bischoff et al., 1997b) attempted to span this interval, from approximately $35 \mathrm{~m}$ to $300 \mathrm{~m}$ core depth.

A second time distribution was made through a portion of these unconstrained sediments independently, using a totally different approach (Litwin et al., 1999). This second method was based on Owens Lake's regional setting, and on the geological and biological processes found within its hydrologic drainage. Owens Lake is only one of a series of lakes along the watershed situated on the leeward (eastern) side of the southern Sierra Nevada. The second lake downstream from Owens Lake is Searles Lake, the older ( $>35 \mathrm{ka}$ ) sediments of which have been dated variously by a number of researchers (Peng et al., 1978; Bischoff et al., 1985; Jannik et al, 1991; Lin et al., 1998). However, no means previously existed to project radiometric dates beyond Searles Lake. Because the two lakes are less than $100 \mathrm{~km}$ apart and lie within the same drainage system, these radiometric ages were potentially valuable for resolving the lack of age control in Owens Lake. A suitable vector for transferring those ages was found by this author, by 
using the pollen rain derived from the Sierra Nevada. This common pollen source is situated windward of both Owens and Searles Lake. It was reasoned that the airborne pollen assemblages: 1) largely were a function of the vegetation occupying the flank of the Sierra Nevada (Litwin et al, 1997, Litwin et al., 1999), 2) changed in character as climate changed, because climatic change forced environmental and thus vegetational changes at the pollen source area, and 3) were deposited as aerosol particles in the same sequence, character, and timing into both lakes (Litwin et al, 1999). From this, it was deduced that a sufficiently finely-resolved pollen sequence from each lake's sediments could become an accurate bridge for transferring radiometric ages from Searles Lake to Owens Lake.

\section{METHOD}

All Searles Lake pollen analyses were made on uncrushed, point-sampled bulk sediment. Some of the Owens Lake analyses were made on powdered and homogenized bulk sediment (below). Point samples were selected carefully from the interior of the core and comprised about 1.0 to 1.5 $\mathrm{cm}$ in stratigraphic thickness. Searles Lake point samples initially were selected at each major change of sediment style, then supplemented with additional interstitial samples taken at approximately 10 to $15 \mathrm{~cm}$ intervals (average). Owens Lake point samples initially were collected at $50 \mathrm{~cm}$ intervals, with each sample representing 1.0 to $1.5 \mathrm{~cm}$ stratigraphic thickness. Additional samples were provided by J.L. Bischoff. Each of those comprised a $10 \mathrm{~cm}$ interval of continuously sampled sediment that was dried, powdered, and homogenized. Collection of point samples at decimeter intervals was discouraged. In all, the signal density was increased by 75 samples in the Searles Lake record and by 245 samples in the Owens Lake record, from the initial suite of samples examined for the first test of this method (Litwin et al., 1999).

Between 2 to 5 grams of dry sample was weighed, decalcified with $10 \% \mathrm{HCl}$, chemically disaggregated in $52 \% \mathrm{HF}$, and separated via centrifugation into organic and inorganic fractions in 
an aqueous $\mathrm{ZnCl}_{2}$ solution that was adjusted to 2.1 specific gravity. The organic residue was pipetted off, rinsed in distilled water, drained, mixed with glycerin jelly, and mounted onto glass slides for light microscope examination and point counting. Analytical counts were based on analyses of 300 specimens per sample. The total estimated number of pollen grains identified and counted for this study interval exceeded 150,000 specimens.

\section{RATIONALE AND RESULTS}

The purpose of this paper is to document the methodology, explain the rationale, and report the recent projection of an example set of radiometric age controls through the Last Interglacial interval, for potential use by other researchers. Age projections were made between the two cores using highly-resolved pollen sequences of juniper (and other members of the allied plant families Taxodiaceae-Cupressaceae-Taxaceae, abbreviated TCT) as the primary signal for matching.

The reasons for this are straightforward. The TCT pollen abundance (i.e., percentage with respect to all terrestrial taxa) in these cores is a proxy for the relative abundance of juniper-piñon woodland along the eastern flank of the Sierra Nevada. This woodland comprises the lowest elevation forest along the Sierran front; below it are steppe and desertscrub biomes (Barbour and Major, 1977; Woolfenden, 1993; Litwin et al., 1997). Because of this position of the juniperpiñon woodland zone in the elevation-banded sequence of vegetation along the Sierran front-and the sensitivity of its lower ecotone-- TCT is a responsive taxon to climate change and thus is a good proxy climate indicator (Litwin et al., 1999). During cold climate intervals-- when alpine glaciers were at their maximum development in the Sierra-much of the physical space currently occupied by upper montane and lower montane forests along the eastern Sierran flank was covered by glaciers, snow fields, or alpine vegetation. This diminished the montane forests spatially, with respect to the areal extent of the juniper-piñon woodland downslope. Mean annual temperatures also were suppressed along elevation gradient of the Sierran front, and the juniperpiñon woodland consequently expanded further downslope to occupy an increased area of 
suitable habitat on the lowest mountain slopes and bajadas (Litwin et al., 1997). Accordingly, juniper-piñon woodland probably increased in total area and in overall proximity to the lakes, resulting in an increased relative TCT signal in lacustrine sediments during cold climate intervals.

Differences in the amplitudes or signal trends in these two records are attributed to the following. First, some local effects in signal probably are present. An increase in juniper woodland around the periphery of Searles Lake, for example, may explain the higher relative abundance of TCT through that feature attributed to interval " $5 \mathrm{~d}$ " in the Searles pollen record. Second, errors in pollen counting also contributed to differences in these two signals, although there was an attempt to minimize this by having one analyst (the author) perform all counts. Counting was a timeintensive exercise; in those samples that were sparse with pollen, where counts were greatly divergent in trend along the sequence, or where non-pollen organic debris cluttered the microscope slide, multiple counts were made on single samples until the results stabilized and were repeatable. Third, powdering of the second sample set from Owens Lake caused extensive breakage in the pollen grains and disaggregation of colonial algal specimens. Accurate pointcounting of broken (partial) pollen specimens and the extra effort needed to distinguish disaggregated and broken Pediastrum cells from TCT specimens (through higher magnification analyses) greatly increased the time necessary for pollen analysis of that sample set, and substantially increased the difficulty in obtaining accurate analyses with repeatable results.

The results of this different age distribution are shown in Figure 2. Control points and ages from Searles Lake core LDW-6 were projected directly from their fixed depths along the Searles Lake pollen sequence to analogous relative positions along the pollen sequence of Owens Lake core OL-92. Sampling density was increased substantially for this report, to test and to correct the initial application of this experiment (Litwin et al., 1999). The two records are plotted against time. The positions of the five control point dates are indicated; lines of correlation mark their 
projection onto the pollen sequence of core OL-92. The age of each control point is labeled on its projection line. Ages are distributed linearly between control points in both cores in Figure 2, and demonstrate the similarity of the pollen sequences. Linear interpolation by depth caused the timing of identical pollen features to differ somewhat in the two cores, in between pairs of control points (see Figure 2, feature 5d). This is expected, because Owens Lake sediments and Searles Lake sediments differ both in absolute thickness and in character through this time interval, with Owens Lake containing dominantly siliciclastic sediments and Searles Lake containing intercalated chemical and siliciclastic sediments) ${ }^{1}$. The five control ages for Searles Lake core LDW-6 noted in this report are $65.5 \mathrm{ka}(+3.3 \mathrm{ky},-3.0 \mathrm{ky}), 69.8 \mathrm{ka}(+1.8 \mathrm{ky},-1.4 \mathrm{ky}), 89.3 \mathrm{ka}(+$ $9.3 \mathrm{ky},-8.2 \mathrm{ky}), 122.3 \mathrm{ka}(+3.6 \mathrm{ky},-3.0 \mathrm{ky})$, and $\sim 134.4 \mathrm{ka}$ (averaged here from $132.4 \mathrm{ka}(+8.2$, $-7.0)$ and $136.4 \mathrm{ka} .(+6.1,-5.1 \mathrm{ka})$, respectively). These control points project to respective positions of $27.35,31.50,51.52,68.38$, and 88.97 meters depth in core OL-92, when the relative position of each control point with respect to the common pollen sequence is conserved. Table 1 therefore provides suggested ages for selected depths from the last interglacial interval in core OL-92. These values are based on linear interpolation between age controls; calculation to two decimal places is for relative placement purposes only-it does not presuppose accuracy at the decadal level.

The results from these more highly-resolved pollen sequences in the two cores suggest that two corrections are necessary for the existing published pollen correlation (Litwin et al., 1999). The first is that the control point at $\sim 122 \mathrm{ka}$ is older than interval " $5 \mathrm{~d}$ ", to which it previously was assigned. The second is that the projection for the control point at $\sim 89 \mathrm{ka}$ is corrected here to $51.52 \mathrm{~m}$ depth in OL-92. Resulting ages for specific depths within this entire stratigraphic interval differ substantially from those initally assigned in Owens Lake, on the basis of the MAR age model (Bischoff et al., 1997b). Through some subintervals, age differences between these

\footnotetext{
${ }^{1}$ The average of the respective ages, where differences exist, is proposed as the best provisional estimate.
} 
two time models approach $20 \mathrm{ky}$. This is nearly twice the current duration of the present interglacial interval, and approximately one-third of the total suggested duration for interval 5 (Figure 3; note the relative placements of interval $5 \mathrm{~d}$ and the $4 / 5$ interval boundary, using the identical pollen dataset plotted against each time model). This new approach results in a time distribution through Owens Lake sediments that is strongly variable with depth and that is consistent geologically, in having coarser-grained sediments deposited more rapidly than finergrained sediments in this lacustrine depositional environment. Accumulation rates probably varied in core OL-92 from approximately $25 \mathrm{~cm} \mathrm{ky}^{-1}$ (or less) for clay-dominated intervals to approximately $170 \mathrm{~cm} \mathrm{ky}^{-1}$ (or more) for coarse sand-dominated intervals (Litwin et al., 1999), rather than having a nearly constant sedimentation rate of approximately $40 \mathrm{~cm} \mathrm{ky}^{-1}$. In summary, this method is useful for importing chronostratigraphic controls into terrestrial records lacking them, and appears to provide the best age distribution yet derived for those OL-92 sediments between approximately $30 \mathrm{~m}$ and $85 \mathrm{~m}$ core depth (the stratigraphic section spanning the entire Last Interglacial interval).

\section{ACKNOWLEDGEMENTS}

The author acknowledges J.P. Smoot for extensive help on conforming core depths and sedimentary fabric in LDW-6 and OL-92, J.Rosenbaum for project support, R.M. Forester for helpful discussion, J.L. Bischoff for powdered samples from OL-92, and N.J. Durika for extensive technical support.

\section{REFERENCES}

Barbour, M.G., and Major, J., eds., 1977, Terrestrial Vegetation of California. John Wiley \& Sons, New York, 1002 pp. 
Benson, L.V., and Bischoff, J.L., 1993, Isotope geochemistry of Owens Lake Drill Hole OL-92:

In Smith, G.I., and Bischoff, J.L., eds., Core OL-92 from Owens Lake, southeast California. U.S.G.S. Open-File Report 93-683, 106-109.

Benson, L.V., Burdett, J.W., Kashgarian, M., Lund, S., Phillips, F.M., and Rye, R.O., 1996, Climatic and hydrologic oscillations in the Owens Lake Basin and adjacent Sierra Nevada, California. Science, 274: 746-749.

Benson, L.V., Burdett, J.W., Lund, S.P., Kashgarian, M., and Mensing, S., 1997, Nearly synchronous climate change in the Northern Hemisphere during the last glacial termination. Nature, 388: 263-265.

Bischoff, J.L., 1993, Age-depth relations for the sediment column at Owens Lake, California: OL-92 Drill Hole: In Smith, G.I., and Bischoff, J.L., eds., Core OL-92 from Owens Lake, southeast California. U.S.G.S. Open-File Report 93-683, 251-260.

Bischoff, J.L., Bullen, T.D., Canavan, R.W., IV, and Forester, R.M., 1998. A test of uranium series dating of ostracode shells from the last interglaciation at Owens Lake, California, Core OL-92: In Bischoff, J.L., The last interglaciation at Owens Lake, California: Core OL-92. U.S.G.S. Open-File Report 98-132, 180-186.

Bischoff, J.L., Menking, K.M., Fitts, J.P., and Fitzpatrick, J.A., 1997a, Climatic oscillations 10,000-155,000 B.P. at Owens Lake, California reflected in glacial rock flour abundance and lake salinity in core OL-92. Quaternary Research, 48(3): 313-325.

Bischoff, J.L., Rosenbauer, R.J., and Smith, G.I., 1985, Uranium-series dating of sediments from Searles Lake: differences between continental and marine climate records. Science, 227: $1222-1224$.

Bischoff, J.L., Stafford, T.W., and Rubin, M., 1997b, A time-depth scale for sediments of core OL-92: radiocarbon dates and constant mass-accumulation rate: In Smith, G.I., and Bischoff, J.L., An 800,000-year paleoclimatic record from Core OL-92, Owens Lake, southeast California. Geological Society of America Special Paper 317, 91-98. 
Bradbury, J. P., 1993, Diatoms in sediments: In Smith, G.I., and Bischoff, J.L., eds., Core OL-92 from Owens Lake, southeast California. U.S.G.S. Open-File Report 93-683, 261-302.

Bradbury, J. P., 1997a, A diatom-based paleohydrologic record of climate change for the past 800 k.y. from Owens Lake, California: In Smith, G.I., and Bischoff, J.L., An 800,000-year paleoclimatic record from Core OL-92, Owens Lake, southeast California. Geological Society of America Special Paper 317, 99-112.

Bradbury, J.P., 1997b, A diatom record of climate and hydrology for the past $200 \mathrm{ka}$ from Owens Lake, California with comparison to other Great Basin records. Quaternary Science Reviews, 16: 203-219.

Bradbury, J.P., and Paquette, M., 1998, Diatom count data and Owens Lake paleolimnology during the last interglacial: In Bischoff, J.L., The last interglaciation at Owens Lake, California: Core OL-92. U.S.G.S. Open-File Report 98-132, 120-141.

Forester, R.M., and Carter, C., 1998, Ostracodes from Owens Lake and the paleoenvironment of the last interglacial: In Bischoff, J.L., The last interglaciation at Owens Lake, California: Core OL-92. U.S.G.S. Open-File Report 98-132, 142-155.

Glen, J.M., and Coe, R.S., 1997, Paleomagnetism and magnetic susceptibility of Pleistocene sediments from drill hole OL-92, Owens Lake, California: In Smith, G.I., and Bischoff, J.L., An 800,000-year paleoclimatic record from Core OL-92, Owens Lake, southeast California. Geological Society of America Special Paper 317, 67-78.

Jannik, N.O., Phillips, F.M., Smith, G.I., and Elmore, D., 1991, A ${ }^{36} \mathrm{Cl}$ chronology of lacustrine sedimentation in the Pleistocene Owens River system. Geological Society of America Bulletin, 103(9): 1146-1159.

Lin, J.C., Broecker, W.S., Hemming, S.R., Hajdas, I., Anderson, R.F., Smith, G.I., Kelley, M., and Bonani, G., 1998. A re-assessment of U-Th and ${ }^{14} \mathrm{C}$ ages for late-glacial high frequency hydrologic events at Searles Lake, California, Quaternary Research, 49(1): 1123. 
Litwin, R.J., 1998, Testing climate stability during the last interglacial interval: pollen evidence from core OL-92: In Bischoff, J.L., The last interglaciation at Owens Lake, California: Core OL-92. U.S.G.S. Open-File Report 98-132, 156-170.

Litwin, R.J., Adam, D.P., Frederiksen, N.O., and Woolfenden, W.B., 1997, An 800,000-year pollen record from Owens Lake, California: preliminary analyses: In Smith, G.I., and Bischoff, J.L., An 800,000-year paleoclimatic record from Core OL-92, Owens Lake, southeast California. Geological Society of America Special Paper 317, 127-142.

Litwin, R.J., Frederiksen, N.O., Adam, D.P., Anderle, V.A.S., and Sheehan, T.P., 1993, Continental-marine correlation of Late Pleistocene climate change: census of palynomorphs from core OL-92, Owens Lake, California: In Smith, G.I., and Bischoff, J.L., eds., Core OL-92 from Owens Lake, southeast California. U.S.G.S. Open-File Report 93-683, 333-391.

Litwin, R.J., Smoot, J.P., Durika, N.J., and Smith, G.I., 1999, Calibrating late Quaternary terrestrial climate signals: radiometrically dated pollen evidence from the southern Sierra Nevada, USA. Quaternary Science Reviews, 18: 1151-1171.

Menking, K., Bischoff, J.L., Fitzpatrick, J.A., Burdette, and Rye, R. O., 1997.

Climatic/Hydrologic oscillations since 155,000 yr B.P. at Owens Lake, California, reflected in abundance and stable isotope composition of sediment carbonate. Quaternary Research, 48: 58-68.

Peng, T.H., Goddard, J.G., and Broecker, W.S., 1978. A direct comparison of ${ }^{14} \mathrm{C}$ and ${ }^{230} \mathrm{Th}$ ages at Searles Lake, California. Quaternary Research, 9(3): 319-329.

Reid, J.B., Jr., Getz, S., and Polissar, P.G., 1995, Highly anomalous C-14 in living biota of the Owens River drainage, Long Valley Caldera, California. AGU Fall Meeting, Abstracts with Program, F652. 
Rosenbaum, J.G., Reynolds, R.L., Smoot, J.P., and Meyer, R., 1998, Testing paleomagnetic sedimentary records using anisotropy of magnetic susceptibility: a re-evaluation of core OL-92 (Owens Lake, California). AGU Fall Meeting, Abstracts with Program, F233.

Sarna-Wojcicki, A.M., Meyer, C.E., and Wan, E., 1997, Age and correlation of tephra layers, position of the Matuyama-Brunhes chron boundary, and effects of Bishop Ash eruption on Owens Lake, as determined from drill hole OL-92, southeast California: In Smith, G.I., and Bischoff, J.L., An 800,000-year paleoclimatic record from Core OL-92, Owens Lake, southeast California. Geological Society of America Special Paper 317, 79-90.

Sarna-Wojcicki, A.M., and Pringle, M.S., Jr., 1992, Laser-fusion ${ }^{40} \mathrm{Ar} /{ }^{39} \mathrm{Ar}$ ages of the tuff of Taylor Canyon and the Bishop Tuff, E. California-W. Nevada [abs.]: Eos, (Transactions, American Geophysical Union), 73: 633.

Woolfenden, W.B., 1993, Pollen present in cores OL-92-1, OL-92-2, and OL-92-3: In Smith, G.I., and Bischoff, J.L., eds., Core OL-92 from Owens Lake, southeast California. U.S.G.S. Open-File Report 93-683, 313-332. 


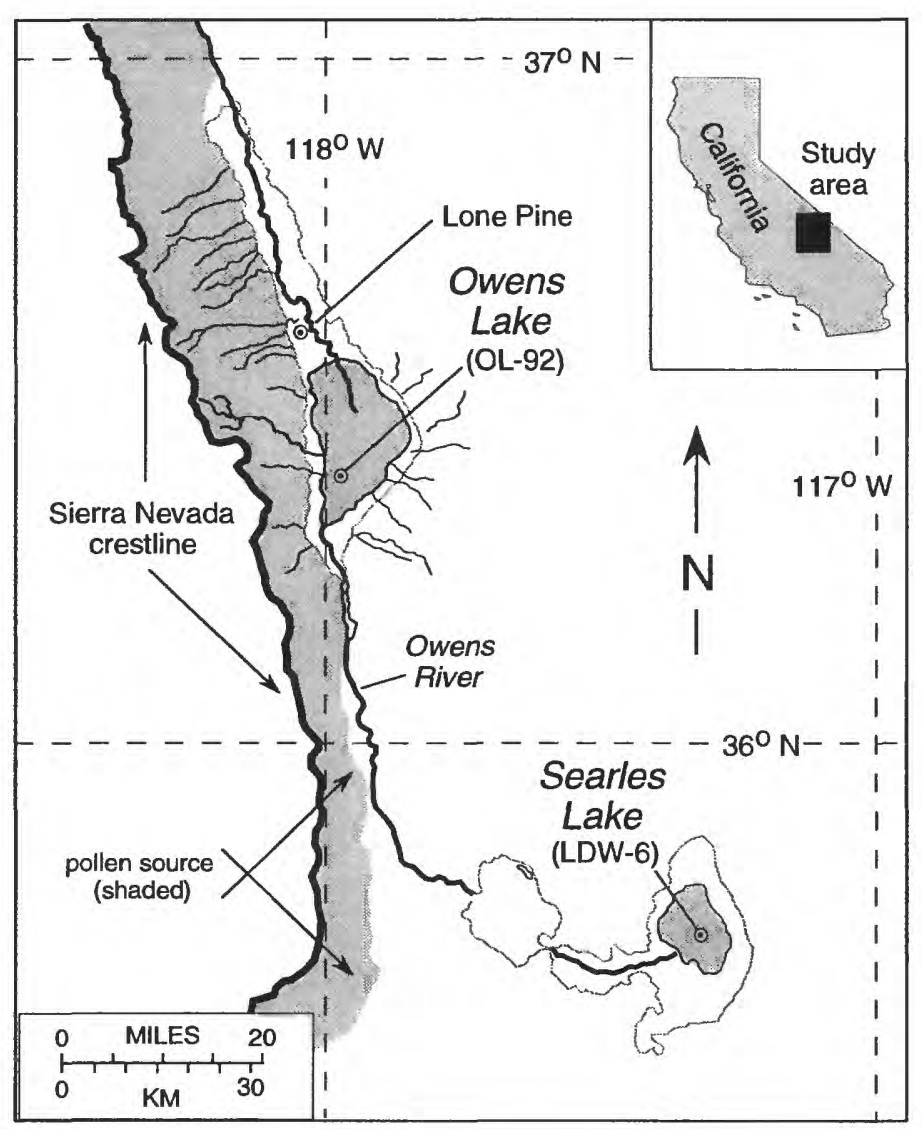

Figure 1. Site map showing the the location and physiographic setting of the two cores used in this report. 


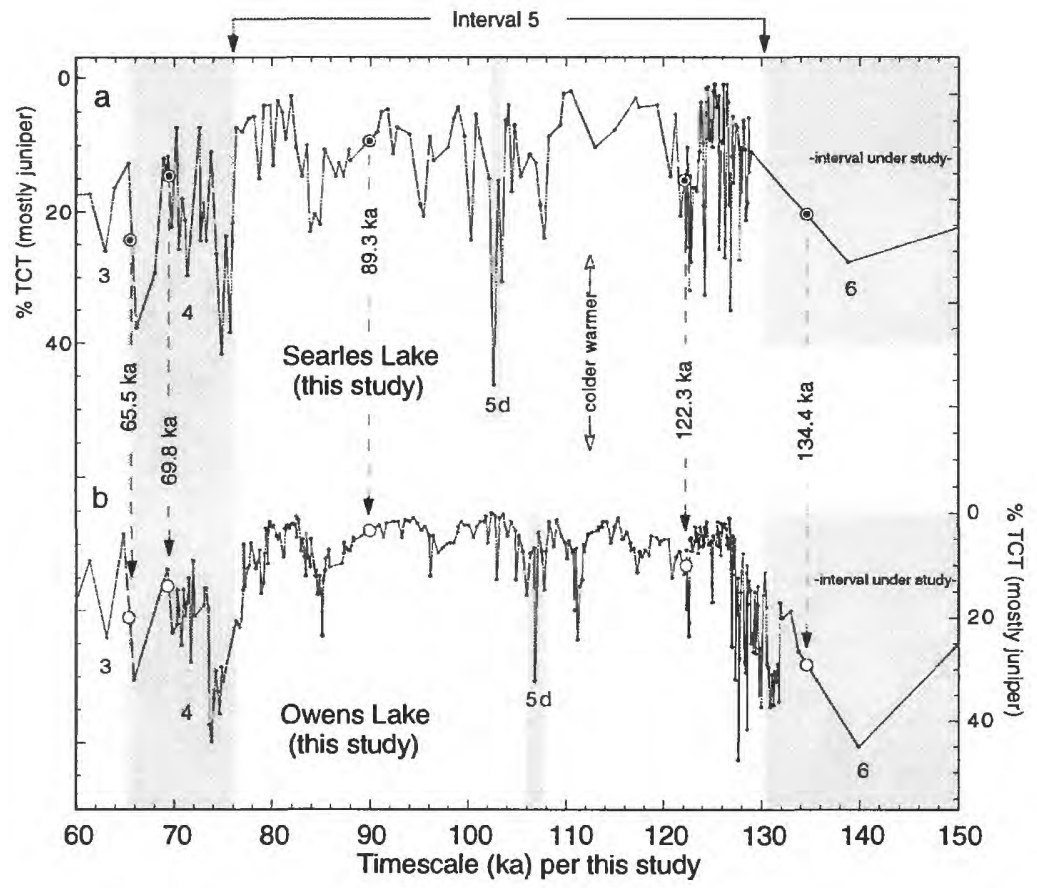

Figure 2. Comparison of Searles Lake and Owens Lake pollen records (TCT) 


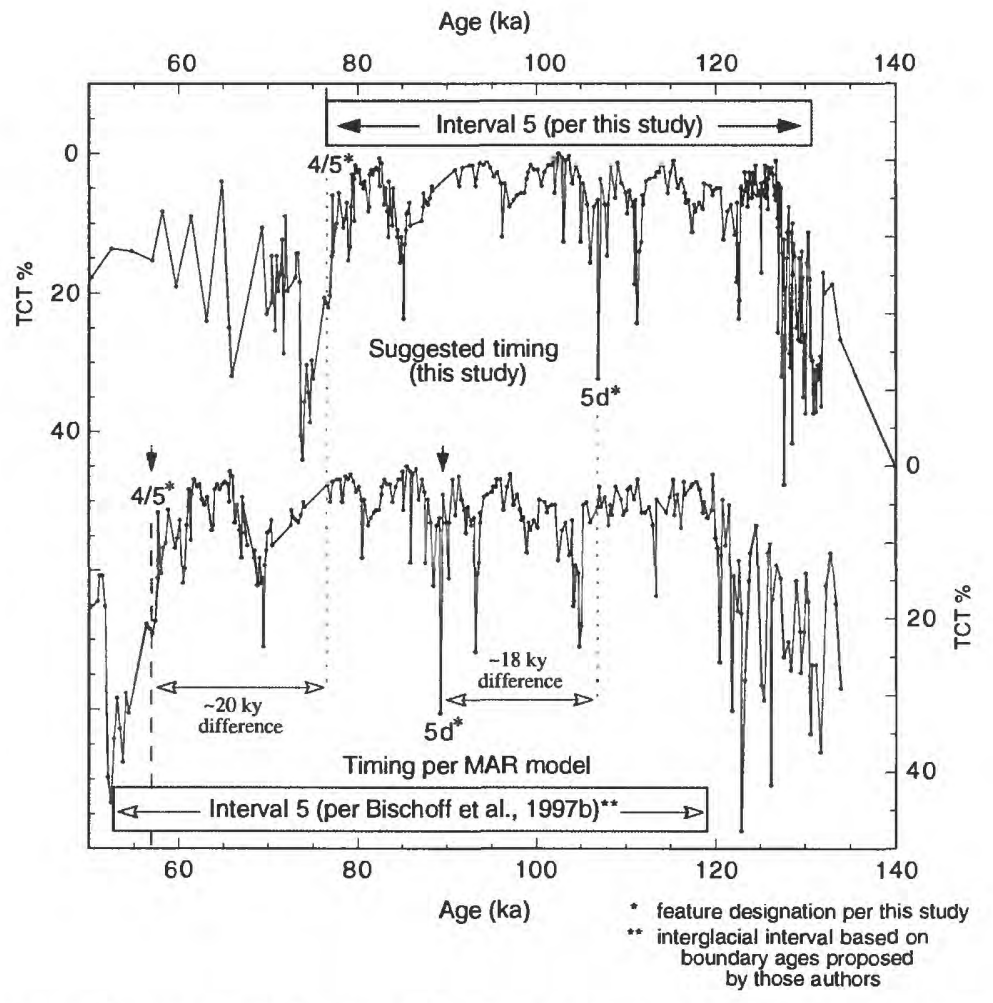

Figure 3. Comparison of timing of the Last Interglacial interval in Owens Lake, core OL-92: this study vs. MAR model (Bischoff et al., 1997a, b) 
Table 1. Selected depths and ages for core OL-92, Owens Lake, California

\begin{tabular}{|c|c|c|c|c|c|}
\hline $\begin{array}{l}\text { Depth (m) } \\
\text { (core OL-92) }\end{array}$ & $\begin{array}{l}\text { Control point age (ka) } \\
\text { (projected via pollen) }\end{array}$ & $\begin{array}{l}\text { Suggested } \\
\text { age (ka) }\end{array}$ & $\begin{array}{c}\text { Depth }(\mathrm{m}) \\
\text { (core OL-92) }\end{array}$ & $\begin{array}{l}\text { Control point age (ka) } \\
\text { (projected via pollen) }\end{array}$ & $\begin{array}{c}\text { Suggested } \\
\text { age (ka) }\end{array}$ \\
\hline 27.35 & 65.50 & 65.50 & 49.85 & & 87.67 \\
\hline 27.50 & & 65.66 & 50.05 & & 87.87 \\
\hline 27.75 & & 65.91 & 50.25 & & 88.06 \\
\hline 31.00 & & 69.28 & 50.45 & & 88.26 \\
\hline 31.25 & & 69.54 & 50.50 & & 88.31 \\
\hline 31.50 & 69.80 & 69.80 & 51.52 & 89.30 & 89.30 \\
\hline 31.75 & & 70.04 & 52.35 & & 90.92 \\
\hline 32.00 & & 70.29 & 52.55 & & 91.32 \\
\hline 32.05 & & 70.34 & 52.75 & & 91.71 \\
\hline 32.45 & & 70.73 & 53.00 & & 92.20 \\
\hline 32.65 & & 70.92 & 53.15 & & 92.49 \\
\hline 32.85 & & 71.11 & 53.35 & & 92.88 \\
\hline 33.00 & & 71.26 & 53.50 & & 93.18 \\
\hline 33.05 & & 71.31 & 53.55 & & 93.27 \\
\hline 33.25 & & 71.50 & 53.75 & & 93.66 \\
\hline 33.45 & & 71.70 & 53.95 & & 94.06 \\
\hline 33.65 & & 71.89 & 54.15 & & 94.45 \\
\hline 33.68 & & 71.92 & 54.35 & & 94.84 \\
\hline 33.85 & & 72.09 & 54.55 & & 95.23 \\
\hline 34.75 & & 72.97 & 54.75 & & 95.62 \\
\hline 34.85 & & 73.06 & 54.95 & & 96.01 \\
\hline 35.05 & & 73.26 & 55.00 & & 96.11 \\
\hline 35.25 & & 73.45 & 55.15 & & 96.40 \\
\hline 35.45 & & 73.65 & 55.25 & & 96.60 \\
\hline 35.65 & & 73.84 & 55.42 & & 96.93 \\
\hline 35.85 & & 74.04 & 55.50 & & 97.09 \\
\hline 36.05 & & 74.23 & 55.65 & & 97.38 \\
\hline 36.25 & & 74.43 & 55.75 & & 97.58 \\
\hline 36.45 & & 74.62 & 55.85 & & 97.78 \\
\hline 36.65 & & 74.82 & 56.00 & & 98.07 \\
\hline 36.85 & & 75.01 & 56.05 & & 98.17 \\
\hline 38.15 & & 76.28 & 56.25 & & 98.56 \\
\hline 38.35 & & 76.47 & 56.45 & & 98.95 \\
\hline 38.55 & & 76.67 & 56.50 & & 99.05 \\
\hline 38.75 & & 76.86 & 56.65 & & 99.34 \\
\hline 38.95 & & 77.06 & 56.75 & & 99.54 \\
\hline 39.00 & & 77.11 & 56.85 & & 99.73 \\
\hline 39.15 & & 77.25 & 57.00 & & 100.03 \\
\hline 39.35 & & 77.45 & 57.05 & & 100.12 \\
\hline 39.55 & & 77.64 & 57.25 & & 100.52 \\
\hline 39.75 & & 77.84 & 57.45 & & 100.91 \\
\hline 40.25 & & 78.32 & 57.50 & & 101.00 \\
\hline 40.45 & & 78.52 & 57.65 & & 101.30 \\
\hline 40.65 & & 78.71 & 57.75 & & 101.49 \\
\hline 40.85 & & 78.91 & 57.85 & & 101.69 \\
\hline 41.05 & & 79.10 & 57.95 & & 101.89 \\
\hline 41.15 & & 79.20 & 58.00 & & 101.98 \\
\hline 41.35 & & 79.39 & 58.25 & & 102.47 \\
\hline 41.50 & & 79.54 & 58.45 & & 102.86 \\
\hline 41.55 & & 79.59 & 58.50 & & 102.96 \\
\hline 41.75 & & 79.78 & 58.65 & & 103.26 \\
\hline 41.95 & & 79.98 & 58.75 & & 103.45 \\
\hline 42.15 & & 80.17 & 58.85 & & 103.65 \\
\hline 42.35 & & 80.37 & 59.00 & & 103.94 \\
\hline 42.55 & & 80.56 & 59.05 & & 104.04 \\
\hline 42.75 & & 80.76 & 59.25 & & 104.43 \\
\hline 43.15 & & 81.15 & 59.45 & & 104.82 \\
\hline 43.25 & & 81.24 & 59.50 & & 104.92 \\
\hline 43.35 & & 81.34 & 59.65 & & 105.21 \\
\hline 43.55 & & 81.54 & 59.75 & & 105.41 \\
\hline 43.75 & & 81.73 & 59.85 & & 105.60 \\
\hline 43.95 & & 81.93 & 60.00 & & 105.90 \\
\hline 44.15 & & 82.12 & 60.05 & & 106.00 \\
\hline 44.35 & & 82.32 & 60.25 & & 106.39 \\
\hline 44.50 & & 82.46 & 60.45 & & 106.78 \\
\hline 44.55 & & 82.51 & 60.50 & & 106.88 \\
\hline 44.75 & & 82.71 & 60.65 & & 107.17 \\
\hline 44.95 & & 82.90 & 60.75 & & 107.37 \\
\hline 45.15 & & 83.10 & 60.85 & & 107.56 \\
\hline 45.35 & & 83.29 & 61.00 & & 107.86 \\
\hline 45.50 & & 83.44 & 61.05 & & 107.95 \\
\hline 45.55 & & 83.49 & 61.25 & & 108.34 \\
\hline 45.75 & & 83.68 & 61.45 & & 108.74 \\
\hline 45.95 & & 83.87 & 61.50 & & 108.83 \\
\hline 46.00 & & 83.92 & 61.65 & & 109.13 \\
\hline 46.50 & & 84.41 & 61.75 & & 109.32 \\
\hline 46.55 & & 64.46 & 61.85 & & 109.52 \\
\hline 46.75 & & 64.65 & 62.00 & & 109.81 \\
\hline 46.95 & & 84.85 & 62.05 & & 109.91 \\
\hline 47.00 & & 84.90 & 62.15 & & 110.11 \\
\hline 47.15 & & 65.04 & 62.25 & & 110.30 \\
\hline 47.25 & & 85.14 & 62.45 & & 110.69 \\
\hline 47.35 & & 85.24 & 62.50 & & 110.79 \\
\hline 47.50 & & 85.38 & 62.57 & & 110.93 \\
\hline 47.55 & & 85.43 & 62.63 & & 111.05 \\
\hline 47.75 & & 85.63 & 62.72 & & 111.22 \\
\hline 47.89 & & 85.76 & 62.83 & & 111.44 \\
\hline 47.95 & & 85.82 & 62.95 & & 111.67 \\
\hline 49.25 & & 87.09 & 63.00 & & 111.77 \\
\hline 49.45 & & 87.28 & 63.05 & & 111.87 \\
\hline 49.50 & & 87.33 & 83.25 & & 112.26 \\
\hline 49.65 & & 87.48 & 63.45 & & 112.65 \\
\hline
\end{tabular}


Table 1. Selected depths and ages for core OL-92 (cont'd).

Depth (m) Control point age (ka) Suggested (core OL-92) (projected via pollen) age (ka)

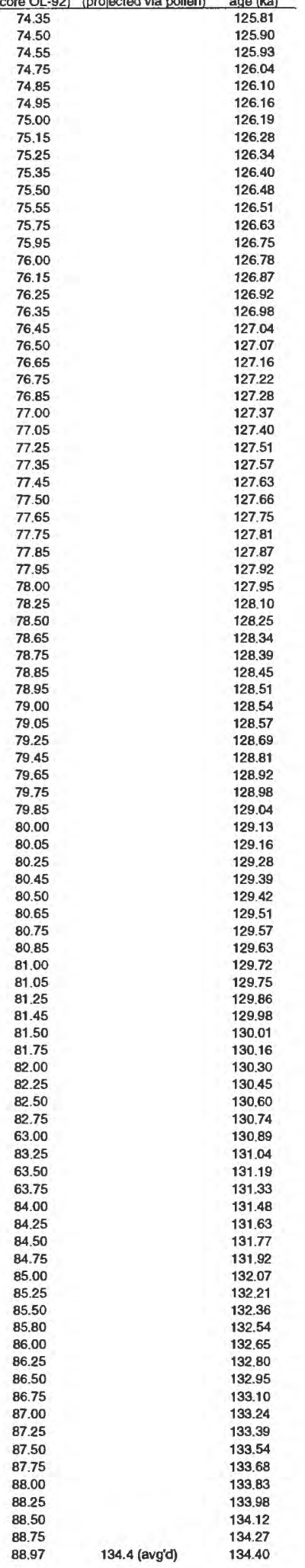

$\begin{array}{ll}88.97 & 134.4(\text { avg'd) } \quad 134.40\end{array}$ 